\begin{tabular}{|c|c|} 
Available online at: http://ejournal-balitbang.kkp.go.id/index.php/ifrj \\
e-mail:ifrj.puslitbangkan@ gmail.com \\
INDONESIANFISHERIESRESEARCHJOURNAL \\
Volume 25 Nomor 1 June 2019 \\
p-ISSN: 0853-8980 \\
e-ISSN: 2502-6569
\end{tabular}

\title{
POPULATION DYNAMIC AND SPAWNING POTENTIAL RATIO OF SHORT MACKEREL (Rastrelliger brachysoma Bleeker, 1851) IN THE NORTHERN COAST OF JAVA
}

\author{
Achmad Zamroni ${ }^{\star 1}$ and Tri Ernawati ${ }^{1}$ \\ ${ }^{1}$ Researcher of Research Institute for Marine Fisheries, Cibinong, Komp. Raiser Ikan Hias, Jl. Raya Bogor KM. 47 Nanggewer \\ Mekar, Cibinong, Bogor Jawa Barat, Indonesia \\ Received; March 06-2018 Received in revised from August 01-2018; Accepted August 21-2018
}

\begin{abstract}
Short mackerel fish (Rastrelliger brachysoma) is one of small pelagic fish mostly exploited by mini purse seine fishing gear. Exploitation of short mackerel by mini purse seine has an increasing trend every year and suspected to have negative impacts. One of the negative impact is the decrease of fish abundance, so it is necessary to carry out population dynamics and Spawning Potential Ratio (SPR) studies through length-based approach to provide exploitation indicator as biology reference point. The result of length-weight relationship analysis shows that the growth pattern $(b$ $=2.3483$ ) is negative allometry. The estimated length at first capture and its first sexual maturity analysis shows that the value of length at first capture $(\mathrm{LC}=15.4 \mathrm{~cm} \mathrm{FL})$ is greater than the length at first sexual maturity $(\mathrm{Lm}=15.21 \mathrm{~cm} \mathrm{FL})$. The estimated maximum length $\left(\mathrm{L}_{\infty}\right)$ is $21.05 \mathrm{~cm} \mathrm{FL}$ with growth rates $(K)$ is 1.01 year- 1 and t0 at -0.177 years. The estimated total mortality $(Z)$ was 5.48 year-1, natural mortality $(M)$ was 2.02 year- 1 and fishing mortality $(F)$ was 3.46 year-1. The predicted exploitation rate $(E)$ is 0.63 which higher than the optimum value $(E=0.5)$. The estimated length-based SPR (LB-SPR) of $30 \%$ (SPR $>20 \%$ or above limit) means that short mackerel fishing activity has full exploitation.
\end{abstract}

Keywords: Growth parameter; northern Java; short mackerel; spawning potential ratio

\section{INTRODUCTION}

Small pelagic fish resources are economically important resources in Java Sea waters based on national statistical data from 2005 to 2015 . The average catch of small pelagic fish is $37.8 \%$ of the total catch, even in 2005 catch of small pelagic fish reached $40 \%$ of the total catch (DGCF, 2016). Rastrelliger is abundantly distributed in Indonesian waters, is and caught in Java Sea, and significantly contributes to marine fisheries production (Sudjastani, 1974). Short mackerel (Rastrelliger brachysoma) is a small pelagic fish species that lives in coastal waters (neritic), and spread out almost along the north coast of Java, Madura Strait, west coast of South Sumatra, and south coast of Kalimantan (Ketapang, Kota Baru) (Zamroni et al., 2008). The exist of short mackerel is generally followed by exploitation using mini purse seine (length of vessel $10-18 \mathrm{~m}$ ) active since 1987 in Pekalongan (Potier \& Sadhotomo, 1995), which is only active in fishing in coastal waters with only one day operation (small scale fisheries) (Zamroni et al., 2008). This type of mini purse seine fishing fleet mainly comes from
Tuban (east or north Java) and Brebes (western part of north central Java). The intensive fishing activity from year to year caused the abundance of short mackerel fish to decrease (Hariati et al., 2003). According to national statistical data, from 2005 to 2016 number of active mini purse seine vessel in 2006 are 11,731 units and in 2016 increased to 24,548 units (DGCF, 2017). In general, exploitation by mini purse seine has resulted in high fishing pressure almost in all areas (Nurhakim, 1993), because the short mackerel species is one of fishing targets of these fisheries.

Recent information on population dynamics especially for short mackerel in the northern waters of Java still needs to be updated following the dynamic of fishing tactic and strategy. In addition, this information is needed for sustainable fisheries management purposes, which is one of them is by studying the condition of the stock dynamic of resources. Currently, the Spawning Potential Ratio (SPR) approach has evolved as a biology reference point. This approach uses length-frequency data as 
input and is used in fisheries with poor data availability (data-poor fisheries), namely the Length-based Spawning Potential Ratio (LB-SPR) (Hordyk etal., 2015b; Hordyk et al., 2015c). The SPR is commonly used to indicate the stock status, by setting the limit and target reference points for the fisheries (Clark, 2002). The purpose of this study is to determine the population parameters to analyze the status of short mackerel resource stock in the waters of North Java. The results of this study are expected to be used as a basic input for sustainable and responsible management of short mackerel fisheries.

\section{MATERIALS AND METHODS}

Regular biological sampling (Rastrelliger brachysoma) was conducted at Pekalongan Fishing Port, Central Java (Figure 1) from January to November 2016. Length and weight samples of fish were obtained from mini purse seine catchoperated in north of Java waters. The parameters measured were fork length with 0.1 $\mathrm{cm}$ accuracy and weight with $0.1 \mathrm{~g}$ accuracy. The sample size collected during the study was 3,479 samples.

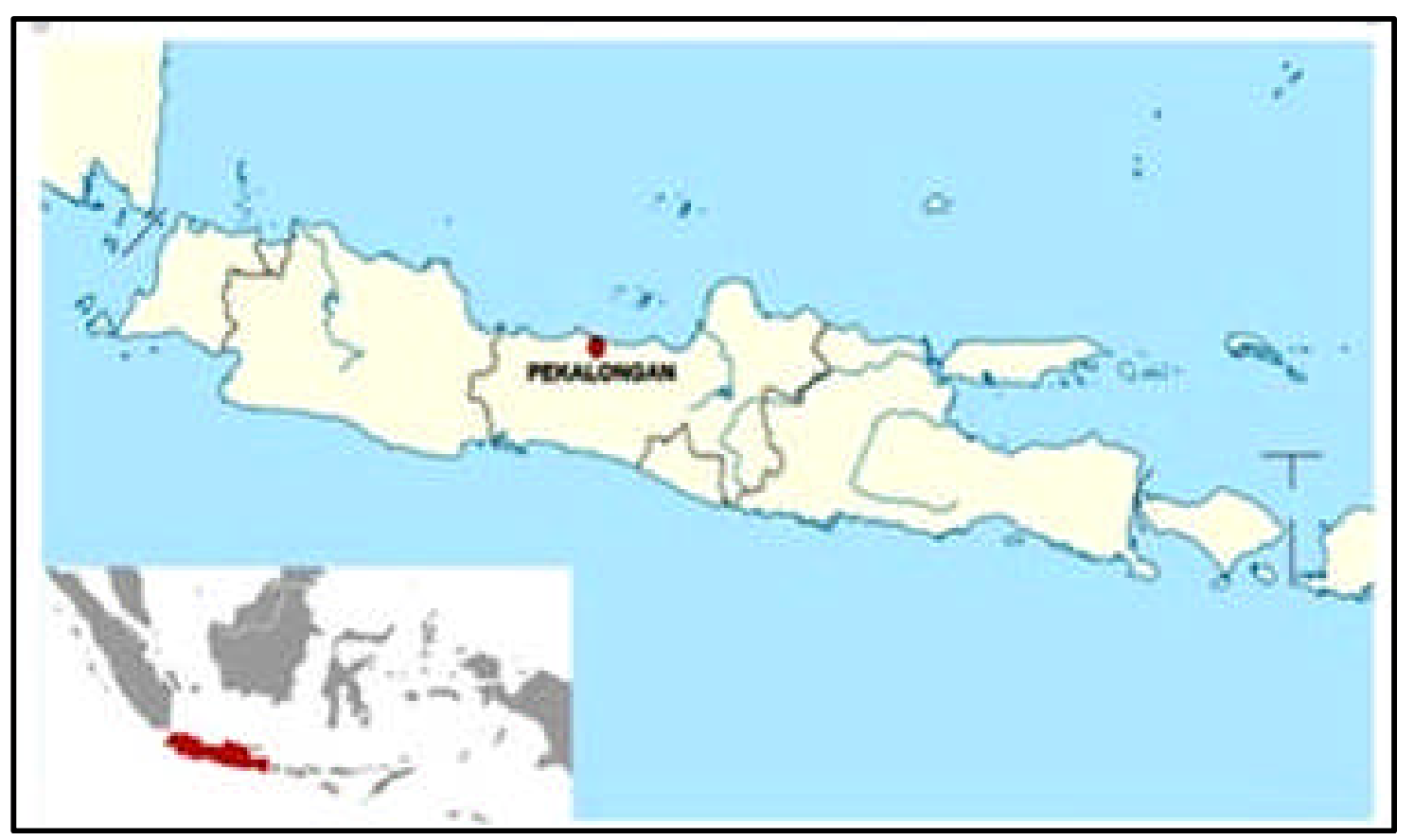

Figure 1. Map of sampling site.

The estimated value of length ( $S L$ ) was calculated using Beverton \& Holt method in Sparre \& Venema (1992):

$$
S L=\frac{1}{a+\exp (a-b L)}
$$

Where the values of $a$ (intercept) and $b$ (slope) are calculated by linear regression estimation as follows:

$$
L n=\frac{1}{\left(S L_{c}-1\right)}=a-b L
$$

Where $L=$ mean length value $(\mathrm{cm})$ and $S L_{C}=$ relative cumulative frequency of length. The $L_{c}$ can be calculated by the equation:

$$
L_{c}=\frac{-a}{b}
$$

The length at first sexual maturity $\left(L_{m}\right)$, expressed by the proportion of the size at $50 \%$ of the short mackerel fish with already ripe gonads, was calculated using equation (King, 2007):

$$
P=\frac{1}{1+e^{-a(L-L m)}}
$$

Where $P=$ the proportion of mature fish at length class $L ; L=$ mean length class; $a=$ a constant

Equation (4) was transformed into a form:

$\operatorname{Ln}\left[\frac{(1-P)}{P}\right]=a L_{m}-a L$

Where the intercept of equation (5) is $a L_{m}$ so that the $L_{m}$ value is:

$L_{m}=$ intercept $(a) /$ slope $(a)$

The growth rate $(K)$ and maximum length $\left(L_{\infty}\right)$ of the fish was assumed to follow Von Bertalanffy Growth 
Function (VBGF). These growth parameters were obtained using the VBGF fitted in FAO-ICLARM Stock Assessment Tool (FiSAT). According to VBGF as expressed below, individual fishes grows on average toward the maximum length at an instantaneous growth rate $(K)$ with length at time $(t)$ following the expression (Sparre \& Venema, 1992):

$L t=L_{\infty}\left[1-e^{-K(t-t o)}\right]$

Where: $L t=$ length $(\mathrm{cm})$ at age, $t ; L_{\infty}=$ asymptotic length $(\mathrm{cm}) ; K=$ growth constant $\left(\mathrm{yr}^{-1}\right) ; t_{0}=$ theoretical age at length zero.

The theoretical age at birth $\left(t_{0}\right)$ was calculated using the empirical formula (Pauly, 1984):

$\log \left(-t_{0}\right)=-0.392-0.275 \log L_{\infty}-1.038 \log K$

The total mortality coefficient $(Z)$ was estimated by linearizing length-converted catch curve analysis (Sparre \& Venema, 1992). Natural mortality of the fish stock was estimated using (Pauly, 1980):

$\log M=-0.0066-0.279 \log L_{\infty}+0.6543 \log K+$ $0.4634 \log T$........

Where, $M=$ natural mortality and $T\left({ }^{\circ} \mathrm{C}\right)=$ annual mean water temperature.

The fishing mortality $(F)$, describing the rate of mortality due to fishing activities, was estimated from the relationship (Ricker, 1975 in Sparre \& Venema, 1992):
$\mathrm{Z}=\mathrm{F}+\mathrm{M}$

The exploitation rate $(E)$ was calculated from the equation (Ricker, 1975 in Sparre \& Venema, 1992):

$E=F / Z$

The length frequency data were pooled into groups with $0.5 \mathrm{~cm}$ length intervals. Then, the data was analyzed using the FiSAT II (FAO-ICLARM Stock Assessment Tools) software (Gayanilo et al., 2005).

The SPR in this study uses the recently developed LB-SPR model by Hordyk et al. (2015b). The inputs to LB-SPR model are: $M / k, L_{\infty}$, the coefficient of variation of the maximum length $\left(C V_{L_{\infty}}\right)$, as well as parameters for the size-at-maturity. The LB-SPR analysis was done in $\mathrm{R}$ software using LB-SPR package in the site of The Barefoot Ecologist's Toolbox Length-Based Spawning Potential Ratio (http:/ /barefootecologist.com.au/lbspr) developed by Shiny (Hordyk et al., 2016).

\section{RESULTS AND DISCUSSION \\ Results \\ Distribution of Sample Size}

Short mackerel fish samples measured during this study were 3,479 samples and the size of frequency distribution in the commercial catches ranged from 12 to $20 \mathrm{~cm}$ of fork length. Fish in the size class of $16 \mathrm{~cm}$ dominated the catches that accounted at about $23.8 \%$ (Figure 2).

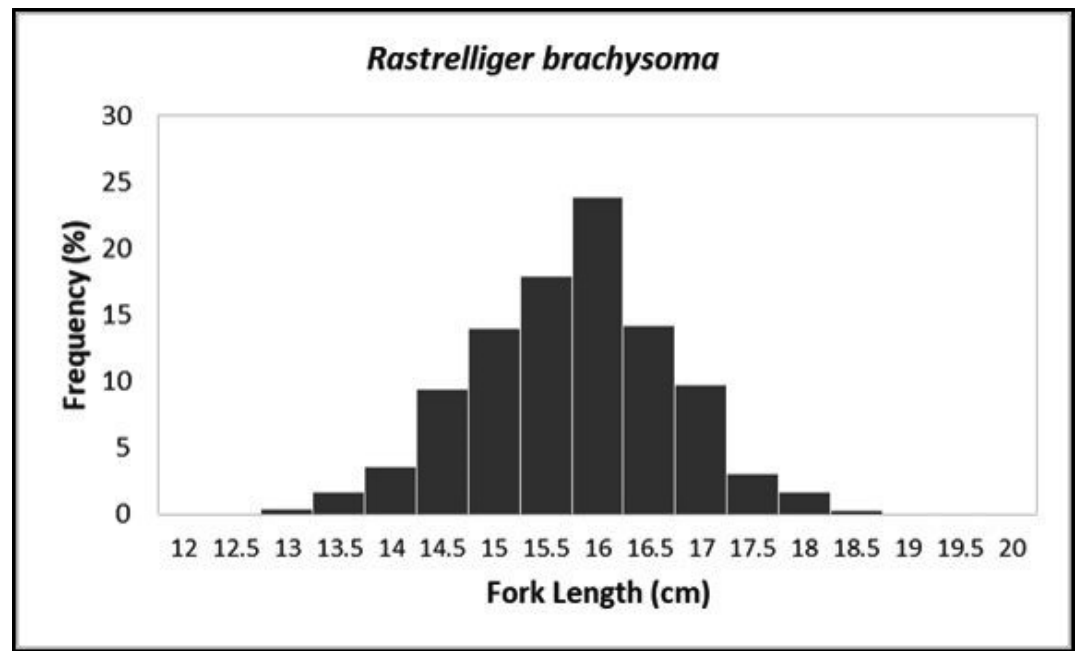

Figure 2. Sample's length distribution of short mackerel from Pekalongan Fishing Port. 


\section{Length at First Capture and at First Sexual Maturity}

The length at first capture (the length at which 50\% of the fish at that size are vulnerable to capture) was estimated as $L c=15.4 \mathrm{~cm}$ of fork length (with $a=$ $30.7 ; b=-1.989 ; R^{2}=0.994$ ). The length at first sexual maturity are very important parameter in fisheries research to assess the optimum length of first capture of a species. This study indicates that the short mackerel fish attains its first sexual maturity $(L m)$ at $15.21 \mathrm{~cm}$ of fork length. The analysis result shows that the length at first capture is higher in value than the length at first sexual maturity.

\section{Growth Parameters}

The growth parameters: maximum length $\left(L_{\infty}\right)$ and growth constant $(K)$ were estimated $21.05 \mathrm{~cm} F L$ and 1.01 year $^{-1}$, respectively. The calculated of $t_{0}$ was at 0.177 years and von Bertalanffy growth equation derived was: $L t=21.05\left[1-\mathrm{e}^{-1.01(t+0.177)}\right]$ (Figure 3). Thus, short mackerel fish can reach its maximum length $(21.05 \mathrm{~cm}$ of fork length) at 36 months. The fishery was dominated by fish of 1 year and 2 years old classes. Both the length at first capture $(L C=$ $15.4 \mathrm{~cm} \mathrm{FL})$ and the length at first maturity $\left(L_{m}=15.21\right.$ $\mathrm{cm} \mathrm{FL)} \mathrm{correspond} \mathrm{to} \mathrm{an} \mathrm{age} \mathrm{(tc)} \mathrm{of} 15$ months.

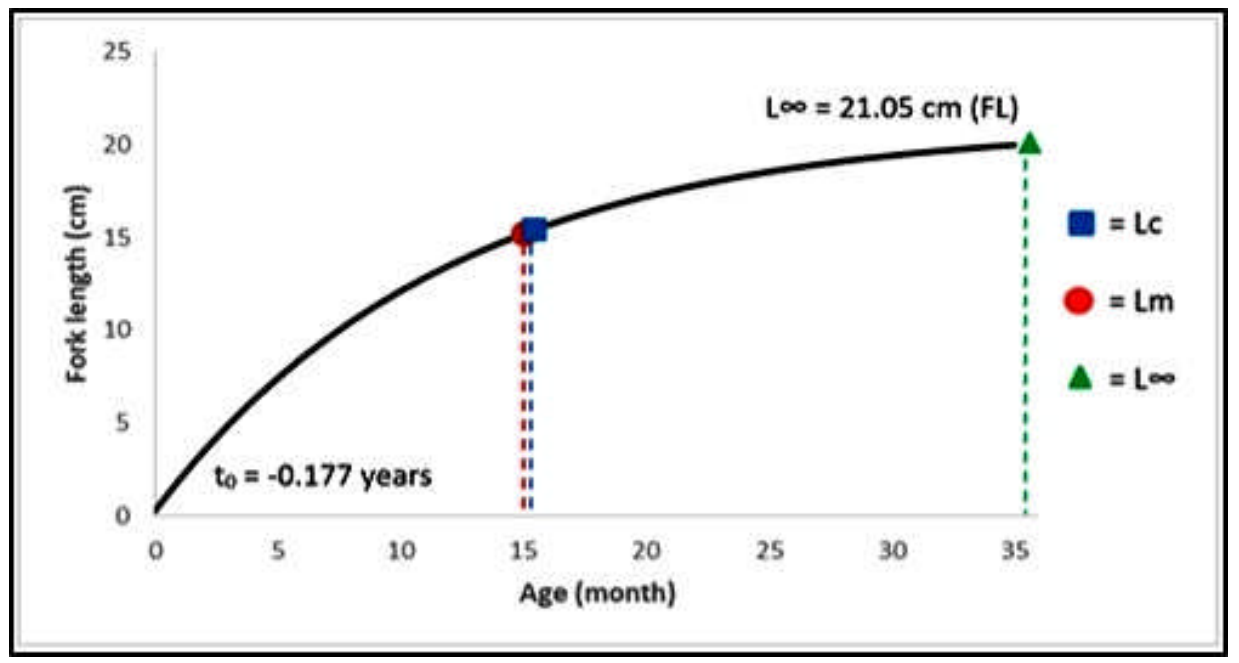

Figure 3. The von Bertalanffy growth model and population parameters of short mackerel from Pekalongan Fishing Port.

\section{Mortality and Exploitation Rates}

Total mortality coefficient $(Z)$ was estimated as $5.48 \mathrm{yr}^{-1}$ using length converted catch method. Natural mortality $(M)$ was estimated at $2.02 \mathrm{yr}^{-1}$ (temperature $\left.=29^{\circ} \mathrm{C}\right)$. Based on $Z$, fishing mortality $(F)$ was found to be $3.46 \mathrm{yr}^{-1}$. Using the fish stocks assessment approach in the tropics (Pauly, 1980), the estimation of exploitation rate was obtained from the estimated capture data structure, at length. The exploitation rate $(E)$ of 0.63 shows that the fishery was seemed to be higher than the optimum level of exploitation $(E=$ 0.50).

\section{Estimated Spawning Potential Ratio (SPR)}

Length based-SPR (LB-SPR) approach is used to more specifically find out the level of exploitation of fish resources in a fishing area. This approach is used in data-poor fisheries that usually occur in small-scale fisheries (Hordyk et al., 2015b). By inputting some parameters, such as length frequency data, maximum length $\left(L_{\infty}, M / K\right.$ ratio (ratio of natural mortality to growth constant) and length at first sexual maturity $\left(L_{m}\right)$ in application of the Barefoot Ecologist's Toolbox Length-Based Spawning Potential Ratio, the result of analysis shows that SPR value is 30\% (SPR $>20 \%$ or above limit) (Figure 4). This SPR value (30\%) illustrates that there are about $30 \%$ of short mackerel fish populations that have opportunities to spawn. Based on Prince et al. (2015), this SPR value shows that the short mackerel fishing activity has been fully exploited, while SPR value of $20 \%$ is the biological limit reference point and SPR value of $40 \%$ is the point of sustainable utilization or sustainability reference point. 


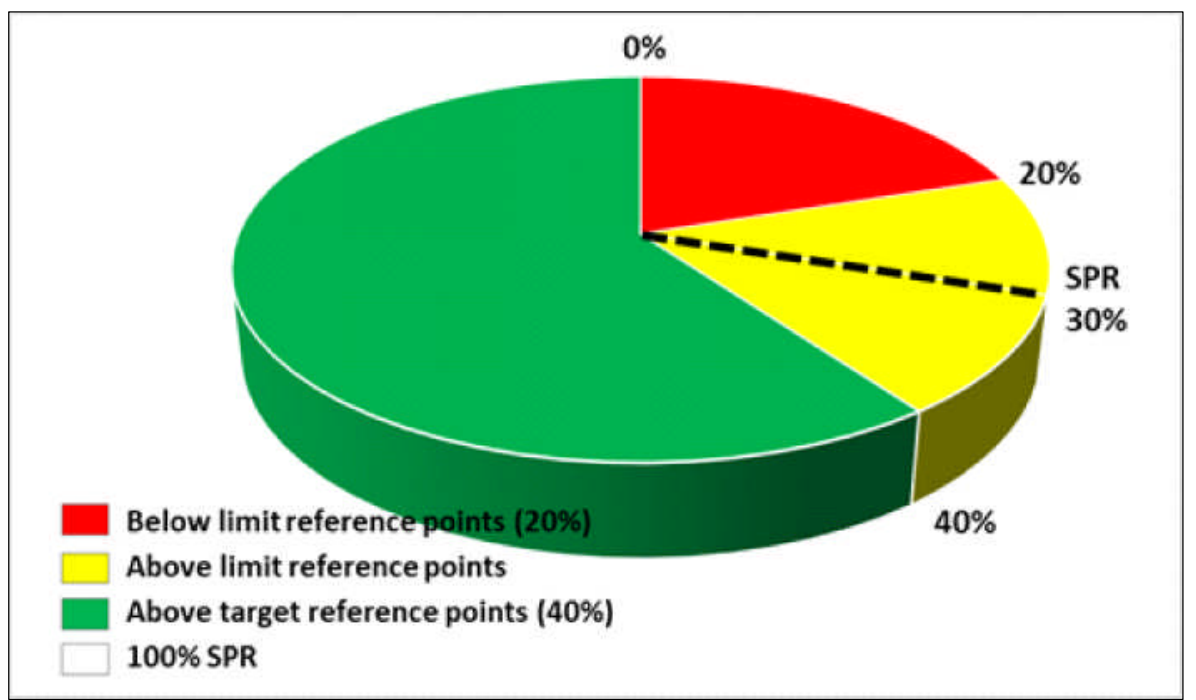

Figure 4. LB-SPR of short mackerel from Pekalongan Fishing Port.

\section{Discussion Length at First Capture and at First Sexual Maturity}

The size of length at first capture in this study is lower than the size obtained by Suwarso \& Hariati (2003) in the same waters (15.8 cm FL) Malacca Strait (15.5 cm FL,Suwarso et al., 2015b). According to Hargiyatno et al. (2013), the difference in the size of length at first capture is due to the differences in the mesh size of fishing gear used, time of fishing (month or season), and fishing ground. In addition, the use of length-based data has some limitations, such as sample size and interval width (Erzini, 1990). The length at first sexual maturity in this study is lower than ones conducted by Suwarso \& Hariati (2003) and Suwarso et al. (2015a) in the Java Sea waters that were $17.1 \mathrm{~cm} \mathrm{FL}$ and $16.4 \mathrm{~cm} \mathrm{FL}$, respectively. The study conducted in t the Malacca Strait shows the size of length at first sexual maturity is $16.9 \mathrm{~cm}$ FL. The differences observed in maturity size are probably because of the influence of ocean environment on the biology of the fish (Ghosh et al., 2016). Fish that get high fishing pressure will tend to have mature gonads at smaller sizes (Trippel et al., 1997). According to Effendie (2002), the length at first sexual maturity is not the same for each species also in the same species, if spread over different latitudes greater than five degrees, it will differ in age and length at first sexual maturity. Similarly, it is expressed by Udupa (1986) that the difference in length at first sexual maturity varies greatly in either different species or the same species, thus fish of the same age or length do not necessarily reach the same size of length at first sexual maturity. The size of length at first sexual maturity is influenced by environmental changes, especially temperature (Karna \& Panda, 2011). Unfavorable environments affect the process of fish reproduction, resulting in slow gonadal maturation (Beyer et al., 2012).

In this study, the length at first capture is greater than the length at first sexual maturity $\left(L_{c}>L_{m}\right)$. In theory, the fish has reached mature gonads before the fish is caught, so the recruitment process has not been disturbed. It is also assumed that group of younger fish (sub-adult) have a habit to be in a different area from adult fish. However, the size of length at first capture almost reaches the size of length at first sexual maturity, and even the size of both is almost the same, so it can be assumed that the recruitment process has begun to be disrupted (slightly disturbed). For that, it is recommended in the management to pay attention to increase the size of length at first capture, for example, by applying evaluation and regulation of mesh size on mini purse seine.

\section{Growth Parameters}

According to Sparre \& Venema (1992), the growth coefficient is a parameter that determines how fast a fish reaches its maximum length. Fish that has a high growth coefficient generally has a shorter lifespan (Pauly, 1980). Growth parameter values in this study differ from the results of the research in the waters of the Malacca Strait, where $L_{\infty}$ is $19.1 \mathrm{~cm} \mathrm{FL}$ and $K$ is 1.22 (Suwarso et al., 2015b). Another study about growth parameters can be seen in Table 1. The differences of growth parameters can be caused by the differences of sampling periods, size of fish samples, and fishing grounds (Moazzam et al., 2005). According to Widodo (1988), the differences of growth parameters are more influenced by the size composition of samples than by the methods used. If the fish samples are predominated by small size fish, 
Tabel 1. Growth parameters ( $L_{\infty}$ and $K$ ) of short mackerel from different studies

\begin{tabular}{cllll}
\hline No. & \multicolumn{1}{c}{$L_{\infty}(\mathbf{c m})$} & \multicolumn{1}{c}{$\boldsymbol{K}\left(\right.$ year $\left.^{-1}\right)$} & \multicolumn{1}{c}{ Location } & \multicolumn{1}{c}{ References } \\
\hline $\mathbf{1 .}$ & $22.9, \mathrm{TL}$ & 2.28 & Tanjung Satai & Sudjastani, 1974 \\
2. & $22.9, \mathrm{TL}$ & 1.8 & Java Sea & Dwiponggo et al., 1986 \\
3. & $26.5, \mathrm{TL}$ & 1.05 & Asahan & Anonymous, 1985 \\
4. & $28.5, \mathrm{TL}$ & 1.4 & Guimaras Strait & Lavapie-Gonzales et al., 1997 \\
$\mathbf{5 .}$ & 22, SL & 1.42 & Phuket & Boonraksa, 1988 \\
6. & $21.05, \mathrm{FL}$ & 1.01 & Pekalongan & Thisstudy \\
\hline
\end{tabular}

higher growth coefficients will be obtained; otherwise, if the fish samples consist of larger fish, smaller growth coefficients will be obtained. Amin et al. (2015) said that the differences of growth parameters are due to age, sex, maturity, and sampling period for the same species.

The differences of growth parameters (1.01 to 2.28 ) can also be due to differences in geographical location, water conditions, and food supply (Effendie, 2002). The differences in environmental parameters, food availability, predation, exploitation, and type of fishing gears used influence the growth parameters (Ghosh et al., 2016). According to Suwarso \& Wujdi (2015), the maximum length differences can be affected by the differences in habitat conditions and the pressure of fishing activities in each of the waters. Furthermore, Suwarso \& Wujdi (2015) said that habitats with nutritional content or the availability of sufficient natural food can support optimal growth of fish, while intensive fishing activities do not give a chance of fish to grow larger so that the maximum length becomes smaller.

\section{Mortality and Exploitation Rates}

Previous study by Dwiponggo et al. (1986) in the Java Sea the value of $Z$ is 7.4 year $^{-1}$, the value of $M$ is 2.83 year $^{-1}$, and the value of $F$ is 4.57 year $^{-1}$. Meanwhile, a study in the Southwest Coast of Phuket showed that the values of: $Z$ is 11.27 year $^{-1}, M$ is $2.13 \mathrm{yr}^{-1}$, and $F$ is 9.4 year $^{-1}$ (Boonraksa, 1988). The mortality rates $(Z, M$ and $F)$ in this study were lower than those conducted by Dwiponggo et al. (1986) and Boonraksa (1988). The differences of mortality rates due to fishing were caused by the differences of the distribution of fish size or age groups, especially the characteristics of distribution of small pelagic fish, like mackerels, which are both temporally and spatially migratory, and have scattered schools habits. In addition, the coefficient of mortality related to fishing is generally influenced by the amount of fishing gear and its intensity; the higher number of fishing gears with higher intensity, the greater mortality coefficient. The differences of mortality rates were caused by different stocks with different fishing pressures to population parameters (Koolkalya et al., 2017).
In this study, the higher estimated value of fishing mortality ( 3.46 year $\left.^{-1}\right)$ than natural mortality (2.02 year $\left.{ }^{1}\right)$ indicates that short mackerel fish are at relatively high fishing pressure. It is also supported by the similar sizes of the length at first capture $\left(L_{c}\right)$ and the length at sexual maturity $\left(L_{m}\right)$. The high rate of fishing mortality and the low rate of natural mortality can also indicate the occurrence of growth overfishing condition that is characterized by the least number of adult fish because of the young fish are caught before reaching adult conditions (Sparre \& Venema, 1992). Therefore, the fishing pressure on the stock should be reduced to reach the optimum condition, which is the rate of fishing mortality is equal to the rate of natural mortality. According to King (2007), a heavy exploited population has a reduced adult fish because of there is no much time to reproduce, and this will result in the absence of stock recruitments into the fishery.

The rate of exploitation $(E)$ of short mackerel fish derived from the comparison of fishing mortality $(F)$ to natural mortality $(Z)$ of 0.63 means $63 \%$ of mortality of short mackerel species landed in Pekalongan waters is the result of fishing activity during this observation. Gulland (1971) suggested that when the natural mortality and fishing mortality are equal $(E=$ 0.5 ), the stock is in a healthy state and optimally exploited. The exploitation rate $(E=0.63)$ calculated in this study indicates heavy exploitation. This suggests that short mackerel fish populations landed in Pekalongan waters are already in the over exploited levels because their exploitation rate is higher than the optimum value of 0.5 per year.

The rate of exploitation $(E)$ obtained by Dwiponggo et al. (1986), $E=0.62$ (high exploitation indication), is almost identical to this study. This indicates that, for more than 30 years, short mackerel has had high exploitation rates., However, the fishery has still survived. This is because short mackerel has a high growth rate $(K>0.5)$. According to Sparre et al. (1989), fish with low growth rate coefficients will take longer to reach their maximum length, while fish that have high growth rate values take less time to reach their maximum length. The faster to reach the maximum size, the faster the fish to reach the size of mature 
gonads and spawning, so the fish recruitment is not much disturbed despite high exploitation rate.

\section{Spawning Potential Ratio (SPR) Estimate}

Based on Prince (2015), the result of LB-SPR analysis in this study (SPR $=30 \%$ ) shows that the status of short mackerel fish landed in Pekalongan is in fully exploited condition (SPR value of $20 \%$ to 40\%). However, according to Woodhams et al. (2011), SPR values of $25 \%$ to $40 \%$ are in a nearly fully exploited condition. Although the status has not reached over exploited, this result indicates that there will be a potential impact of highly fishing pressure. This can be seen from the value of exploitation rate that is higher than the optimum value $(E=0.63)$. Moreover, the higher value of fishing mortality than natural mortality indicates that the fishing pressure of short mackerel fish in these waters is very high. Another impact of the high value of fishing mortality is the similarity size between the length at first capture $\left(L_{c}\right)$ and the length at first sexual maturity $\left(L_{m}\right)$. Moreover, the value of $L_{c}$ and $L_{m}$ in this study is lower than previous studies. If this condition is continued, it will decrease the SPR value and the length at first capture $\left(L_{c}\right)$. Therefore, it is suggested in the management to focus on decreasing the fishing mortality $(F)$ to reach optimum condition that is equal to the value of natural mortality $(M)$. One way to reduce the value of $F$ is to reduce fishing effort, by controlling fishing permits such as number of units, size of fishing fleet, fishing gear dimensions, and fishing technology.

Assuming the Indonesian government adopts the SPR $20 \%$ as limited reference point, the SPR result on this research $(30 \%)$ is still above the threshold limit. This means that the recruitment process is still not completely disrupted. This can be seen from the higher size of length at first capture than length at first maturity, although only slightly. The high fishing mortality rate on the results of this study has not been so disturbing the recruitment process. It strongly indicates that this spawning area of short mackerel fish has not been exploited, so there are still fish that have chances to be adult fish and even reach mature gonads.

\section{CONCLUSION}

The estimated length at first capture is greater than the length of female at first sexual maturity. This condition can be suitable for the availability of short mackerel fish stock because the fish reach mature gonads before being caught, so the recruitment process has not been disturbed. Maximum length $\left(L_{\infty}\right)$ in this study is $21.05 \mathrm{~cm} \mathrm{FL}$, the value of growth coefficient $(K)$ is $1.01 \mathrm{yr}^{-1}$, and the value of $\mathrm{t}_{0}$ is -0.177 . Estimated value of fishing mortality (3.46 yr-1) is higher than that of natural mortality $(2.02 \mathrm{yr}-1)$, indicating that short mackerel fish in this study are at relatively high fishing pressure. The current exploitation rate $(E=0.63)$ calculated in this study indicates heavy exploitation. The result of LB-SPR analysis based on Prince (2015) shows that the status of short mackerel fish landed in Pekalongan is in fully exploited condition $(\mathrm{SPR}=30 \%)$.

These conclude that the results of this study show differences to statements submitted by Haryati et al. (2003), i.e. intensive fishing activity from year to year causes the abundance of short mackerel fish to decrease and by Nurhakim (1993) about exploitation by mini purse seine has resulted in high fishing pressure. Because the results show that the recruitment process has not been seriously disrupted, as evidenced by the length at first capture values $\left(L_{c}\right)$ is greater than the length at first sexual maturity $\left(L_{m}\right)$, the SPR value is still $30 \%$, and the exploitation rate for more than 30 years has the same value trend. If the fish population has been seriously disrupted, the exploitation rate will be greater, the SPR value will be smallereven reaching less than $20 \%$, and the $L_{c}$ value will also be smaller. This occurs because of high growth rate of short mackerel fish $(>1)$, so the exploitation rate makes insignificant effects on abundance and recruitment.

\section{ACKNOWLEDGEMENTS}

This study is part of research activity entitled Research of Biological Characteristics, Habitat Resources and Potential Production of Fish Resources in FMA 712 in 2016 at Research Institute for Marine Fisheries. We would like to thank Mr. Danu, Mr. Fauzi, and Mr. Suwarso who has helped in providing the literatures. We also thank Mr. Marzuki, Rino, Wahyu, and Nova from Research Institute for Marine Fisheries (RIMF) that has helped in the provision of equipment during the writing of this paper. Finally, to all who have helped and cannot be mentioned one by one, we thank you very much.

\section{REFERENCES}

Amin, A. M., Sabrah, M. M., El-Ganainy, A., \& ElSayed, A. Y. (2015). Population structure of Indian mackerel, Rastrelliger kanagurta (Cuvier, 1816), from the Suez Bay, Gulf of Suez, Egypt. Int. J. Fish. Aquat. Stud, 3(1), 68-74. 
Anonymous, (1985). Report of the Second Working Group Meeting on the Mackerels (Decapterus and Rastrelliger spp.) in the Malacca Strait, 4-9 October 1985, Colombo, Sri Lanka. Bay of Bengal Programme Document. $23 \mathrm{p}$.

Beyer J, Myhre, L. P., Sundt, R. C., Meier, S., Tollefsen, K. E., Vabo, R., Klungsoyr, J., \& Sanni, S. (2012). Environmental risk assessment of alkylphenols from offshore produced water on fish reproduction. Mar. Environ. Res., 75, 2-9.

Boonraksa, V. (1988). Growth, mortality and maximum sustainable yield of the Indo-Pacific mackerel (Rastrelliger brachysoma) off the southwest coast of Thailand. Rome: FAO Fish. Rep, 389, 356-371.

Clark, W. G. W. (2002). F35\% revisited ten years later. N. Am. J. Fish. Manag, 22, 251-257.

Directorate General of Capture Fisheries (DGCF). (2016). Statistik Perikanan Tangkap Indonesia Tahun 2016. DJPT. Jakarta

Directorate General of Capture Fisheries (DGCF). (2017). Statistik Perikanan Tangkap Indonesia Tahun 2017. DJPT. Jakarta

Dwiponggo, A., Hariati, T., Atmadja, S. B., Palomares, M. L. D., \& Pauly, D. (1986). Growth, mortality and recruitment of commercially important fishes and penaeid shrimps in Indonesian waters. Rome: ICLARM Tech. Rep. 17, 91.

Effendie, I. M. (2002). (In Indonesian) Fsheries biology. Bogor: Yayasan Pustaka Nusantara.

Erzini, K. (1990). Sample size and grouping of data for length-frequency analysis. Fish. Res., 9, 355366.

Gayanilo, F., Sparre, P., \& Pauly, D. (2005). FAOICLARM Stock Assessment Tools II (FiSAT II). Revised. User's guide. Computerized Information Series (Fisheries). No. 8. Revised version. Rome: FAO-ICLARM.

Ghosh, S., Rao, M. V. H., Mahesh, V. U., Kumar, M. S., \& Rohit, P. (2016). Fishery, reproductive biology and stock status of the Indian mackerel Rastrelliger kanagurta (Cuvier, 1817), landed along the northeast coast of India. Indian J. Fish, 63(2), 33-41.
Gulland, J. A. (1971). Fish Resources of the Ocean. London: Fishing New Books.

Hargiyatno, I. T., Sumiono, B., \& Suharyanto, S. (2013). (In Indonesian) Catch rate, stock density and some biological aspect of white prawn (Penaeus merguensis) in Dolak waters, Arafura Seas. Bawal, 5(2), 123-129. DOI: http://dx.doi.org/ 10.15578/bawal.5.2.2013.123-129

Hariati, T., Suwarso, Wahyono, M. M., \& Merta, G. S. 2003. (In Indonesian) Mini purse seine activity in the waters of northern coastal of Java and Sunda strait. Prosiding Hasil-hasil Riset. Pusat Riset Perikanan Tangkap, BRKP-DKP, 1-8.

Hordyk, A. R., Loneragan, N. R., \& Prince, J. D. (2015a). An evaluation of an iterative harvest strategy for data-poor fisheries using the lengthbased spawning potential ratio assessment methodology. Fis. Res., 171, 20-32.

Hordyk, A.R., Ono, K., Valencia, S.R., Loneragan, N.R., \& Prince, J. D. (2015b). A novel length-based empirical estimation method of spawning potential ratio (SPR), and tests of its performance, for small scale, data-poor fisheries. ICES J. Mar. Sci., 72, 217-231.

Hordyk, A. R., Ono, K., Sainsbury, K. J., Loneragan, N. \& Prince, J.D. (2015c). Some explorations of the life history ratios to describe length composition, spawning-per-recruit, and the spawning potential ratio. ICES J. Mar. Sci., 72, $204-216$.

Hordyk, A. R., Ono, K., Prince, J. D., \& Walters, C. J. (2016). A simple length-structured model based on life history ratios and incorporating sizedependent selectivity: application to spawning potential ratios for data-poor stocks. Can. J. Fish. Aquat. Sci., 73, 1787-1799.

Karna S. K., \& Panda, S. (2011). Growth estimation and length at maturity of a commercially important fish species i. e., Dayscieaena albida (Boroga) in Chilika Lagoon, India. Euro. J. Exp. Bio., 1(2), 8491.

King, M. (2007). Fisheries Biology, Assessment and Management. Second edition. Oxford: Blackwell Sciencetific Publication. 
Koolkalya, S., Matchakuea, U., \& Jutagate, T. (2017). Growth, population dynamics and optimum yield of indian mackerel, Rastrelliger kanagurta (Cuvier, 1816), in the eastern Gulf of Thailand. IJAT, 13(7.1), 1065-1075.

Lavapie-Gonzales, F., Ganaden, S. R., \& GayaniloJr., F. C. (1997). Some population parameters of commercially important fishes in the Philippines. Philippines: Bureau of Fisheries and Aquatic Resources.

Moazzam, M., Osmany, H. B., \& Zohra, K. (2005). Indian mackerel (Rastrelliger kanagurta) from Pakistan. Some aspects of biology and fisheries. Rec. Zool. Surv. Pakistan, 16, 58-75.

Nurhakim, S. (1993). (In Indonesian) Some reproduction aspek of indian mackerel (Rastrelliger kanagurta) in the Java Sea. Jurnal Penelitian Perikanan Laut, 81, 8-20.

Pauly, D. (1980). On the interrelationships between natural mortality, growth parameters and mean environmental temperature in 175 fish stocks. Journal of Conservation and Exploring Meridien, $39,175-192$.

Paully, D. (1984). Fish population dynamics in Tropical Waters: A Manual for Use With Programable Calculators. Manila: ICLARM.

Potier, M. \& Sadhotomo, B. (1995). Exploitation of the large and medium seiners fisheries. In: Potier and Nurhakim (eds): Biodynex. Seminar Biology, Dynamics and Exploitation of small pelagic in Java Sea. AARD/EEC/ ORSTOM, 195-214.

Prince, J. D., Hordyk, A. R., Valencia, S. R., Loneragan, N. R., \& Sainsbury, K. J. (2015). Revisiting the concept of Beverton-Holt life-history invariants with the aim of informing data-poor ûsheries assessment. ICES J. Mar. Sci., 72, 194203.

Sparre, P., Ursin, E., \& Venema, S. C. (1989). Introduction to tropical fish stock assessment. Part 1: manual. FAO Fish. Tech. Paper n. 306.1. Rome, Italy.

Sparre, P., \& Venema, S. C. (1992). Introduction to tropical fish stock assessment, Part 1. Manual. FAO (Rev. 1). FAO Fish. Tech. Paper n. 306.1. Rome, Italy.
Sudjastani, T. (1974). The species of Rastrelliger in the Java Sea, their taxonomy, morphometry and population dynamics. United Kingdom, UK: University of British Columbia, Thesis.

Suwarso, S., \& Hariati, T. (2003). (In Indonesian) Biology and ecology of small pelagic fish in the northern coast of Java and Sunda Strait. J. Lit Perikan. Ind., 9(7), 29-36. DOI: http://dx.doi.org/ 10.15578/jppi.9.7.2003.29-36

Suwarso, S., Ernawati, T., \& Hariati, T. (2015a). (In Indonesian) Reproductive biology and spawning estimation of short mackerel (Rastrelliger brachysoma) in northern coast of Java. Bawal, 7(1), 9-16. DOI: http://dx.doi.org/10.15578/ bawal.7.1.2015.9-16

Suwarso, S., Hariati, T., Zamroni, A., Fauzi, M., Prasetyo, A. P., \& Kuswoyo, A. (2015b). Fishery and biology of Indian mackerel (Rastrelliger kanagurta, Scombridae) in Indonesian region of the Bay of Bengal Large Marine Ecosystem. Thailand: Bay of Bengal Large Marine Ecosystem Project, Final Report.

Suwarso, S., \& Wujdi, A. (2015). (in Indonesian) Population dynamic and spawning potential ratio of bali sardinella (Sardinella lemuru Bleeker, 1853) in the Prigi Bay, East Java. J. Lit. Perikan. Ind., 21(3), 177-186. DOI: http://dx.doi.org/10.15578/ ippi.21.3.2015.177-186

Trippel, E. A., Kjesbu, O. S., \& Solemial, P. (1997). Effect of adult age and size structure on reproductive output in marine fishes. In $R$. Christopher Chamber and Edward A. Trippel (eds.) Early life history and recruitment in fish populations. Chapman and Hall: Fish and fisheries series 21, 31-62.

Udupa, K. S. (1986). Statistical method of estimating the size at first maturity in fishes. ICLARM, Metro Manila, Fishbyte, 4(2), 8-10.

Walters, C. J., \& Martell, S. J. D. (2004). Fisheries Ecology and Management. Princeton, USA: Princeton University Press.

Widodo, J. (1988). Population Dynamics and Management of Ikan layang (Decapterus spp) (Carangidae) in the Java Sea. Jurnal Penelitian Perikanan Laut, 47, 11-44. 
Woodhams, J., Stobutzki, I., Vieira, S., Curtotti, R., \& Begg, G. A. (2011). Fishery status reports 2010: status of fish stocks and fisheries managed by the Australian Gov. Canberra, AUS: ABARES.
Zamroni, A., Suwarso, S., \& Mukhlis, N. A. (2008). (In Indonesian) Reproductive biology and population genetic of short mackerel (Rastrelliger brachysoma, Famili SCOMBRIDAE) in the northern coast of Java. J. Lit Perikan Ind., 14(2), 215-226. DOI: http://dx.doi.org/10.15578/ jppi.14.2.2008.215-226 